Blockading the Border and Human Rights 


\section{Inter-America Series}

Edited by Howard Campbell, Duncan Earle, and Fobn Peterson

In the new "Inter-American" epoch to come, our borderland zones may expand well past the confines of geopolitical lines. Social knowledge of these dynamic interfaces offers rich insights into the pressing and complex issues that affect both the borderlands and beyond. The Inter-America Series comprises a wide interdisciplinary range of cutting-edge books that explicitly or implicitly enlist border issues to discuss larger concepts, perspectives, and theories from the "borderland" vantage and will be appropriate for the classroom, the library, and the wider reading public. 


\section{Blockading the Border and Human Rights}

The El Paso Operation That Remade Immigration Enforcement

TIMOTHY J. DUNN

University of Texas Press $\mathbf{\sim}$ Austin 
A version of Chapter 4 appeared previously in Pablo Vila, ed., Ethnography at the Border (Minneapolis: University of Minnesota Press, 2003).

Copyright (C) 2009 by the University of Texas Press

All rights reserved

Printed in the United States of America

First edition, 2009

Requests for permission to reproduce material from this work should be sent to: Permissions

University of Texas Press

P.O. Box $78 \mathrm{I} 9$

Austin, TX 78713-7819

www.utexas.edu/utpress/about/bpermission.html

(0) The paper used in this book meets the minimum requirements of ANSI/NIso z39.48-I992 (R I997) (Permanence of Paper).

\section{Library of Congress Cataloging-in-Publication Data}

Dunn, Timothy J., I96I-

Blockading the border and human rights : the El Paso operation that remade immigration enforcement / Timothy J. Dunn. — Ist ed.

p. cm.-(Inter-America series)

Includes bibliographical references and index.

ISBN 978-0-292-7190I-9 (cloth : alk. paper)

I. El Paso (Tex.)-Emigration and immigration. 2. El Paso (Tex.)-

Emigration and immigration-Government policy. 3. El Paso (Tex.)-

Emigration and immigration-Social aspects. 4. Mexico-Emigration and immigration-Social aspects. 5. United States. Immigration Border Patrol.

I. Title. II. Series

JV7IOO.E57D86 2009

$325 \cdot 764^{\prime} 96-\mathrm{dc} 22$ 
To Amy Liebman, and our sons Benjamin and Gabriel.

To my father, Robert "Olie" Dunn, and in memory of my mother, fo Ann Foster Dunn.

And to all those working to make a better world, with justice and dignity for all. 
THIS PAGE INTENTIONALLY LEFT BLANK 